\title{
Determinants of European Firm's Innovation and the Role of Public Financial Support ${ }^{\#}$
}

\author{
Jan Huñady ${ }^{*}-$ Marta Orviská ${ }^{* *}-$ Beata Šarkanová ${ }^{* * *}$
}

\section{Introduction}

Innovations represent one of the key factors leading to increased productivity and competitiveness in the economy. They can be considered as the result of the transformation process of converting the latest ideas into new or improved outcomes. According to Uramová et al. (2003), in the context of R\&D and investment policy, incentives for the genesis of new inventions are created (discoveries, ideas, processes), which subsequently in materialized form represent innovations. The transformation of innovations into economic processes is through investment, while investment in innovation in the private and public sectors, increases productivity and efficiency of production factors. Lisý (2007) stated that the latest knowledge of science and technology proceeds at a robust pace, resulting in considerable dependence of economies on information, knowledge and innovations. The ability to use them is therefore the most important factor for the growth of labour productivity and living standards. The importance of innovation lies in the fact that in the context of creation, dissemination and use of knowledge, they become a key driver of economic growth (Šebo in Benčo, Kuvíková, et. al. 2011, p. 121).

\# This research was supported by the 7FP research project LIPSE ("Learning from Innovation in Public Sector Environments").

Ing. Ján Huňady, PhD. - Assistant Professor; Department of Finance and Accounting. Faculty of Economics, Matej Bel University, Tajovského 10, 97590 Banská Bystrica Slovakia, <jan.hunady@umb.sk>.

** prof. Ing. Marta Orviská, PhD. - Professor; Department of Finance and Accounting. Faculty of Economics, Matej Bel University, Tajovského 10, 97590 Banská Bystrica Slovakia,<marta.orviska@umb.sk>.

*** Ing. Beata Šarkanová - PhD. Student; Department of Finance and Accounting. Faculty of Economics, Matej Bel University, Tajovského 10, 97590 Banská Bystrica Slovakia,<beata.sarkanova@umb.sk>. 
The determinants of innovation at the firm or at national level have been, mostly because of their important implications for economic growth, in the focus of economic research for a longer time. Our analysis brings some new empirical insights to this problem. The main aim of this paper is to identify the potential determinants of innovation and test the importance of external financial support for innovation.

\section{Literature review}

One of the first scientific studies dealing with innovations and their potential impact on economic growth in detail is Schumpeter's work (1937, 1943), which stated that the dynamics of the national economy is influenced by the use of "new combinations" of production factors. These "new combinations" Schumpeter later designated as "innovations", which are understood as a creative destruction by which new products and services are put on the market, that increase productivity and economic growth. Macroeconomic consequences of innovations are also examined in the highly influential work of Solow (1957), who developed the socalled exogenous economic growth model. In this model, the technological progress was used as an exogenous and in the long term the most important variable. Similar considerations also appear in postkeynesian Kaldor's model of economic growth (1972). Romer (1986) and Lucas (1988) later, on the basis of Schumpeter's ideas and neoclassical concepts, created the so-called endogenous model of economic growth. Important elements in these models are learning, research and development, which are seen as the key endogenous factor of economic growth.

In the literature there can be found several definitions of innovation and the innovation process. At the very beginning of the theory of innovation developed by A. J. Schumpeter the concept included: (1) production of a new product or an existing product in new quality, (2) introduction of a new manufacturing process in the production, (3) the use of a new hither-to unknown source of raw materials or semi-products, (4) gaining new markets, or (5) changes in the management and organization of production (Jáč, 2005). Mulgan and Albury (2003) define innovation as the successful implementation of a new or significantly improved product or service, process, a new marketing method, or a new organizational method that will bring substantial improvements to the economy, efficiency and quality of outputs. According to Greenhalgh and Rogers (2010) innovation can be defined as the application of new ideas 
to the product, processes, or other aspects of the activities of a firm that increase „value“. This „value“ should be considered as higher value added for the firm and also benefits to other firms or consumers.

Innovation activities in enterprises depend on several determinants influencing the decision to innovate and invest in research and development. There are several factors influencing the outcome of the innovation process. Zemplinerová, Hromádková (2012) mention the firm's age, the firm's size, and strategic features such as being a member of a group, orientation on foreign markets, barriers to innovation financing, level of market competition, economic situation of the country, R\&D subsidies etc. Vieites and Calvo (2011) identified as determinants of business innovation human resources, and other organizational factors related to research and development (centralization, specialization etc.), financial resources and innovation support, technology resources, information and knowledge management, and research and development activities having the greatest significance in the model. They consider them as key factors that contribute positively to the successful achievement of the innovation objective, but unlike linear models of innovation they do not consider them as a requirement or pre-requisite for success in the innovation process.

In general, we can divide potential determinants of innovation in the enterprise into internal and external ones. Internal factors include for example, company size, company age and export orientation. External factors might include e.g. conditions in a particular country, the intensity of competition in the domestic market, cooperation with external institutions or financial support of innovation from the state or other institutions. The impact of these factors is empirically tested in the analytical part of the paper.

Regarding a size of firm as determinant of innovation activities in companies, already Schumpeter (1942) emphasized the positive relationship between size and innovation. On the other hand, some empirical studies fail to provide a clear picture, without reaching unanimous conclusions concerning significance, magnitude or sign of the relationship between size and innovation activities in firms. For example Koudelková (2014) found no significant relationship between the company size and successful innovation in the case of small and medium enterprise in the Czech Republic. However, most of the studies (e.g. Scherer 1992, Cohen and Klepper 1996) show a positive relationship between the intensity of R\&D and the size of a company. Other studies 
(Acs and Audretsch, 1988) have found a negative or (Aghion et al. 2005, Zemplinerova 2010) even an inverted-U shaped relationship between the size and the intensity of R\&D in companies.

As mentioned by Svidroňová and Mikuš (2014), several authors point out that it is necessary to take into account the external environment in which innovation processes take place (Fagerberg, 2006, Osborne \& Brown, 2005). Within this environment innovation processes influence political, economic, socio-cultural and technological factors (Bekkers \& Homburg, 2007). Economic implementation of innovation is therefore mostly dependent on the mutual cooperation of all interested economic entities - enterprises, government and households.

One of the potentially most important external factors of innovation is the degree of competition in the market. According to Boone and Van Dijk (1998) if R\&D is effective enough (if innovation is not too costly), a rise in competition increases total $\mathrm{R} \& \mathrm{D}$ expenditures. Under these circumstances a rise in competition results in an increase in the probability of persistence of leadership. Lesáková (2014) stated that small and medium enterprises are forced to make innovation, because of permanent pressure of competitors at the market. Boone (2001) finds that in highly competitive industries, the most advanced firms innovate and vice-versa in weakly competitive industries. As competition becomes more intense, the leader gains, if he is ahead far enough. Aghion et al. (2005) show an inverted-U pattern between competition and innovation in their empirical results: firms populate both the low competition regime where there is a positive relation between competition and innovation, and the high competition regime where there is a negative relation. This analysis was performed for firms listed on the London Stock Exchange during the 1973 - 1994 period, the conclusion is that a non-monotonic competition-innovation relationship is not only theoretically plausible, but there is empirical evidence for the presence of both regimes. Aghion et al. (2005) argue a causal relationship: the level of innovation activities depends on the level of competition. Regarding the inverted- $U$ relation, it is shown to be a special case when all individual innovations are very large, and even then only under special conditions.

Obviously, innovations would not be possible without the financial resources enabling the transformation of new ideas and innovation activities in enterprises. From the perspective of investment theory, innovation investments have a number of characteristics that make them different from ordinary investments. A large part of these investments, 
focused on research and development is in practice often from more than half made up of salaries and wages of scientists and engineers. Their efforts are concentrated in the creation of an intangible asset, the firm's knowledge base, from which the firm will benefit in the future. This knowledge embedded in the human capital of the firm is therefore in case of retirement or dismissal lost (Hall, 2005).

Based on the survey conducted on 857 firms Lesáková (2014) concluded that the lack of financial resources is the main barrier to developed innovation activates for small and medium enterprises in Slovakia. Klemet (2014) also confirm that the biggest obstacle for increasing the intensity of innovation in Slovakia seems to be the lack of own capital. According to the author the government has to eliminate a high administrative burden for firms related to the provision of financial support for innovation. This situation seems to be similar also in several other countries. Public support for private innovation is often provided by government in the form of significant public subsidies to R\&D. The aim is to promote and stimulate innovation activities of firms and subsequently the economic growth. It is argued that because companies have problems to appropriate benefits associated with innovation, private firms invest in R\&D innovation less than would be socially desirable and public subsidy thus reduces high and uninsurable risk of the decision to innovate (Zemplinerová, Hromádková, 2012). There are several empirical studies that confirm that external financial support has a significantly positive effect on firm's innovation activities and performance. For example Chang and Jang (2008) based on the logistic regression performed on the sample of 1014 Korean firms conclude that financial support systems have a significant effect on both product and processes innovation. Lerner (1999) found out that long-run performance of hightechnology firms receiving public venture capital was better. This has been reflected in higher employment and sales.

However, the total amount of financial support is not the only problem for the support of innovation. Another key issue is the allocation of the resources to certain countries and regions. Šipikal, Pisár and Uramová (2010) analysed the support of innovation on a regional level of V4 countries (Czech Republic, Hungary, Poland and Slovakia). The authors stated that despite the top level of innovation infrastructure as well as innovation results in metropolitan regions (like Prague and Bratislava) most of the resources from EU on innovation are allocated to other than these regions. Therefore, these resources can be misallocated for so-called "cathedral in the desert" projects, which may not have the 
desired effect on economic growth. The paper also emphasizes the problems connected with lack of coordination in innovation policies across the regions.

\section{Data and methodology}

The data from Flash Eurobarometer 394 survey have been used in the empirical analysis. This survey has been carried out in January and February 2014 and includes the firm's answers on questions about innovation activities, commercialization of innovation as well as public support of innovation. The survey has been conducted using ad hoc telephone interviews at the request of European Commission. All questions and answers of this survey have been summarized and graphically illustrated in European Union (2014). Together 12108 firms from Switzerland, USA and $28 \mathrm{EU}$ member states have responded to the questions. However, we used only the data for the EU countries in our regressions. Moreover, the dataset has been further reduced to 9845 observations due to elimination of non-response cases. We conduct the logit as well as probit regression analysis. Due to better interpretation of the results, the odds ratios have been reported in the case of logit regression and the marginal effects have been calculated for probit regression models.

There are several questions from the survey that are useful for our purposes. Perhaps the most crucial question asks whether the firms introduced any of the following type of innovation since January 2011. The innovations are further classified on innovative goods, services, processes, marketing strategies and organizational structures. We focused our attention on innovation of goods, services and processes. These answers on three binary choice questions have been used in the regression models as the dependent variable. Answers to the first question referring to innovative goods clustered by the country are shown in Figure 1. As we can see the majority of companies in the sample do not significantly improve in this respect since January 2011 in all countries accept Malta and Portugal. 
Huňady, J. - Orviská, M. - Šarkanová, B.: Determinants of European Firm 's Innovation and the Role of Public Financial Support.

Fig. 1: Innovation of goods in EU countries, Switzerland and USA

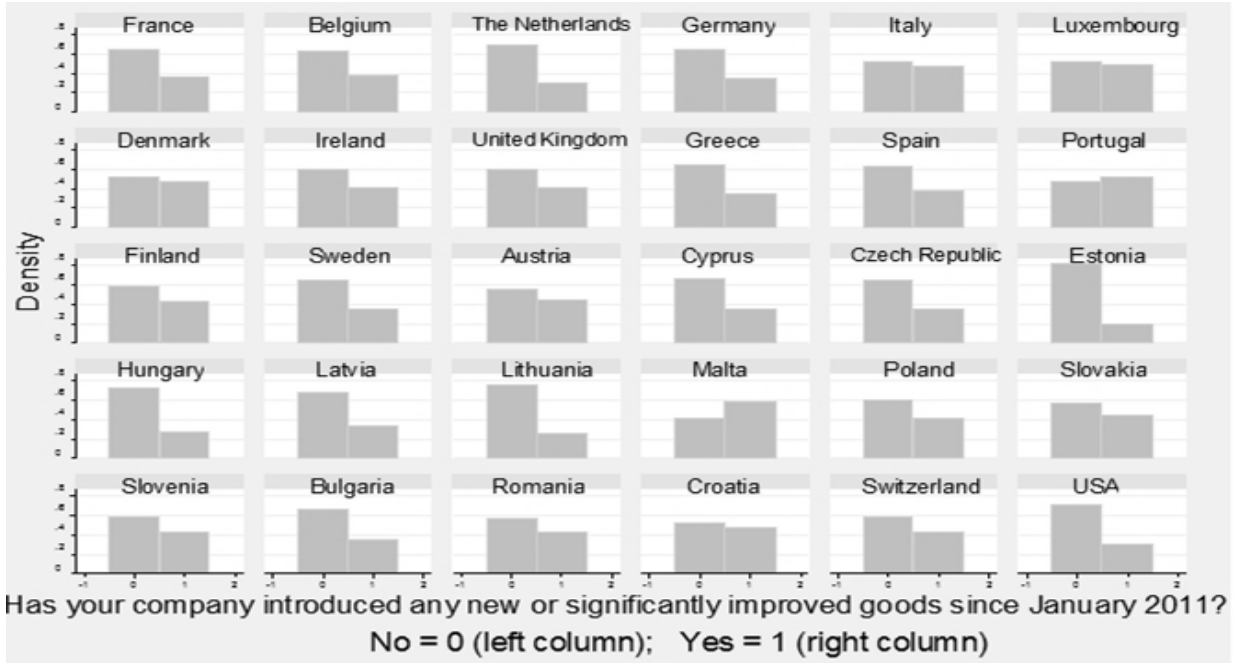

Source: Calculated by authors from data in Flash Eurobarometer 394 using STATA.

However, there are rather big differences among countries. Firms from Estonia, Lithuania and Hungary are less innovative in respect to goods innovation. The innovation of services is most frequent in the case of Croatian, Portuguese and Irish firms as it can be seen in Figure 2.

\section{Fig. 2: Innovation of services in EU countries, Switzerland and USA}

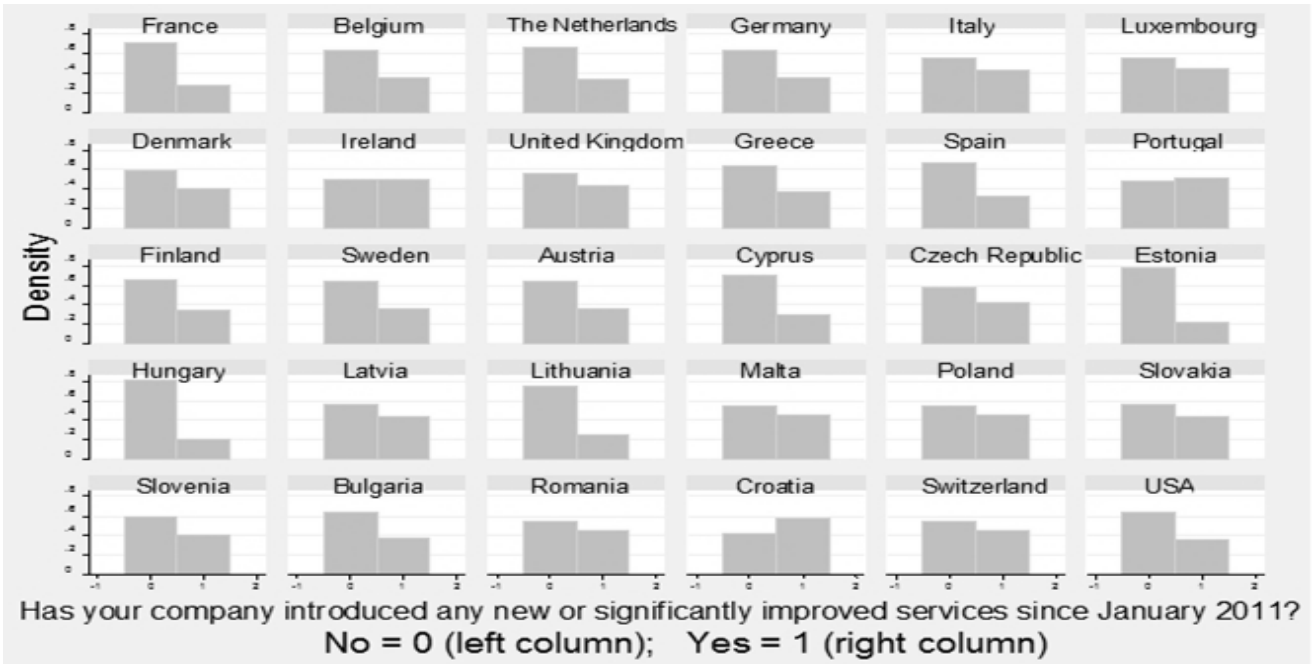

Source: Calculated by authors from data in Flash Eurobarometer 394 using STATA. 
The positive relationship between innovation of services and goods seems to be also evident. The innovation of services appears to be mostly more common in the countries which are leaders in innovation of goods and vice versa. The same is also mostly true in respect of process innovations shown in Figure 3. However, process innovation is significantly less common than innovation of goods or services in several countries, such as Slovakia, Poland or Romania.

\section{Fig. 3: Innovation of processes in EU countries, Switzerland and USA}

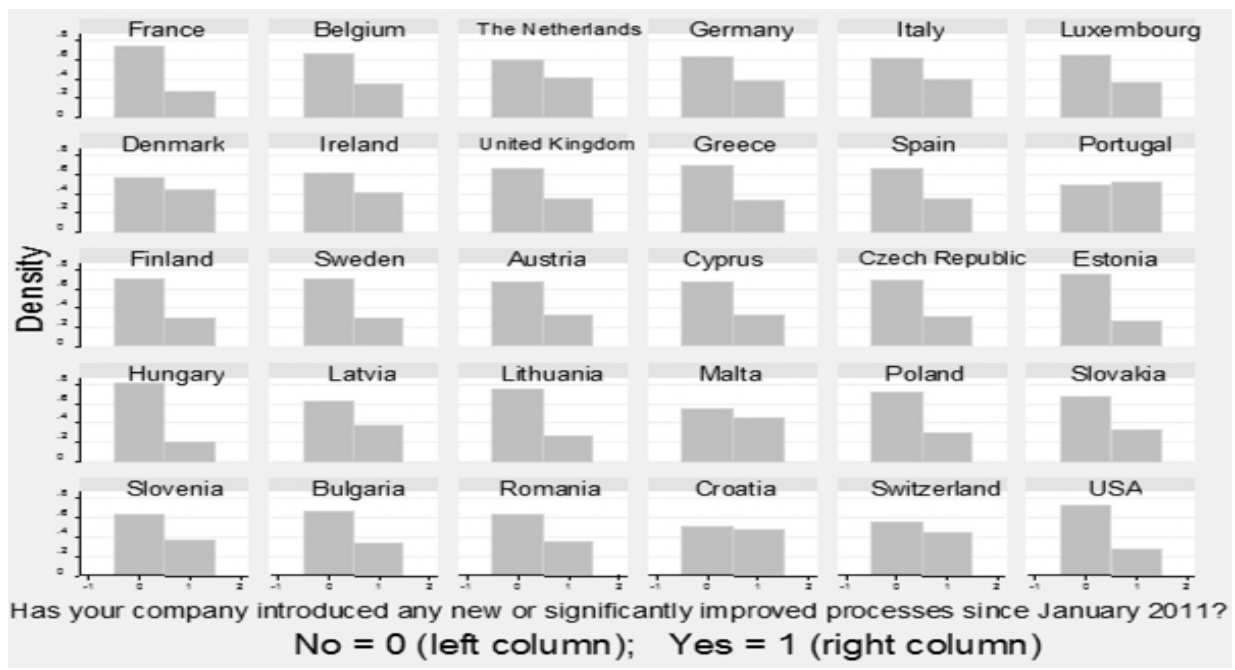

Source: Calculated by authors from data in Flash Eurobarometer 394 using STATA.

Further questions used in the analysis are summarized in the Table 1. The answers to these questions have been used as independent variable in regression models. The number of employees has been classified into four groups. In overall there are 4707 firms with less than 10 employees, 3344 firms are in the range between 10 and 49 employees, 1971 firms have more than 50 but less than 249 employees, 337 firms is in the interval of 250 to 499 and 286 respondents answered that they have more than 500 employees. Less than forty firms have been established after 1st January 2013 and 1248 firms have been founded between the 1st January 2008 and 1st January 2013. On the other hand, 9350 firms have been established before 1 January 2008, which is the vast majority. The average reported company's turnover is more than $104,277 €$ in year 2013, while more than $12 \%$ of this turnover came in average from exports. 3500 firms have reported that their businesses are focused primarily on services, 2613 companies are in the retail sector, 2371 are 
Huňady, J. - Orviská, M. - Šarkanová, B.: Determinants of European Firm 's

Innovation and the Role of Public Financial Support.

manufacturing firms and 2161 have classified themselves as an industrial firm.

Tab. 1: The question used in the regressions

\begin{tabular}{|c|}
\hline 1. How many employees (full-time equivalent) does your company currently have? \\
\hline 2. When was your company established? \\
\hline 3. What was your company's total turnover in 2013 ? \\
\hline 4. Approximately what percentage of your company's turnover in 2013 came from exports? \\
\hline 5. Does your company sell its goods or services to individual consumers? \\
\hline 6. Does your company sell its goods or services to public sector? \\
\hline 7. NACE code of the firm (4 Categories: Manufacturing, Industry, Retail, Services) \\
\hline 8. Country based on firm's country code \\
\hline 9. EU 15 countries (original EU member states until 1.5.2004) \\
\hline $\begin{array}{l}\text { 10. Has your company collaborated with any of the following partners for the marketing, } \\
\text { distribution or promotion of any of your goods or services since January } 2011 \text { ? ... A competitor }\end{array}$ \\
\hline $\begin{array}{l}\text { 11. Has your company collaborated with any of the following partners for the marketing, } \\
\text { distribution or promotion of any of your goods or services since January 2011? ... A partner } \\
\text { company or an external consultant }\end{array}$ \\
\hline $\begin{array}{l}\text { 12. Has your company collaborated with any of the following partners for the marketing, } \\
\text { distribution or promotion of any of your goods or services since January } 2011 \text { ?... A client } \\
\text { company or individual consumers }\end{array}$ \\
\hline $\begin{array}{l}\text { 13. Has your company collaborated with any of the following partners for the marketing, } \\
\text { distribution or promotion of any of your goods or services since January } 2011 \text { ?... Public sector } \\
\text { organisation }\end{array}$ \\
\hline 14. How would you judge the competition of your company in its main market? \\
\hline $\begin{array}{l}\text { 15. Has your company received any public financial support for research and development or } \\
\text { other innovation activities from any of the following since January } 2011 ? . . \text { local government }\end{array}$ \\
\hline $\begin{array}{l}\text { 16. Has your company received any public financial support for research and development or } \\
\text { other innovation activities from any of the following since January } 2011 \text {... national government }\end{array}$ \\
\hline $\begin{array}{l}\text { 17. Has your company received any public financial support for research and development or } \\
\text { other innovation activities from any of the following since January } 2011 \text { ?... European union }\end{array}$ \\
\hline $\begin{array}{l}\text { 18. Has your company received any public financial support for research and development or } \\
\text { other innovation activities from any of the following since January 2011? ... Other }\end{array}$ \\
\hline $\begin{array}{l}\text { 18. Since January } 2011 \text { has your company carried out research and development (R\&D) either } \\
\text { in-house or by subcontracting? }\end{array}$ \\
\hline
\end{tabular}

Source: Authors. 
Companies in the sample are relatively evenly distributed among all EU countries. The largest number of firms is from Spain and France (483 and 459 firms). Slovak and Czech companies were represented in the sample with 334 respectively 360 respondent firms.

\section{Results and Discussion}

The main motivation of firms to introduce some kind of innovation is to raise the turnover and then the profit. In the Figure 4 we can see how firms on average perceive the effect of introduced innovation on their turnover. Most of them assumed that innovation activities introduced since January 2011 linked to 1 to $25 \%$ of the company's turnover in 2013.

\section{Fig. 4: The approximate percentage of company's turnover in 2013} due to innovative goods and services introduced since January 2011.

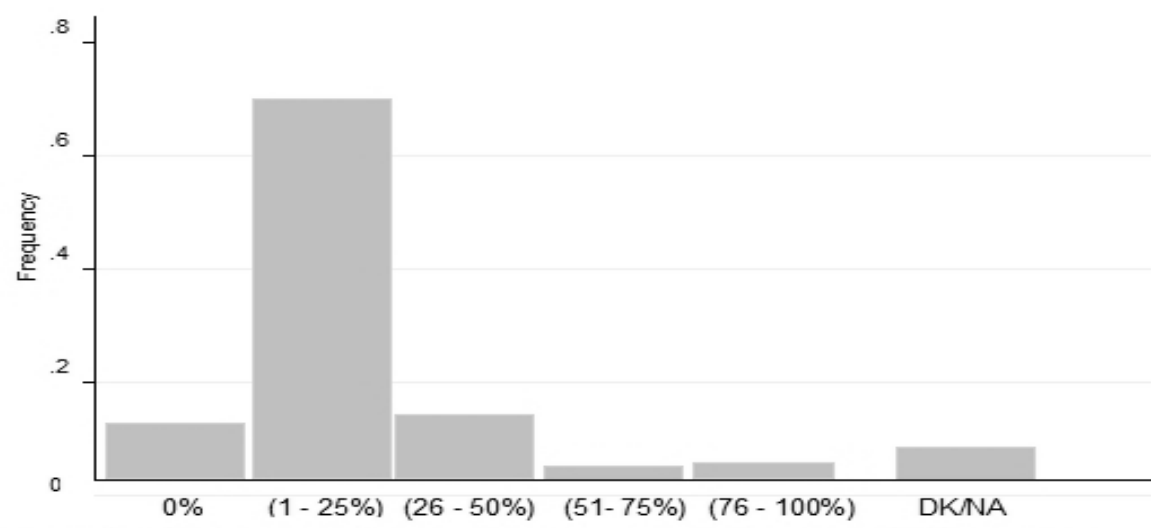
Q2 Approximately what percentage of your company's turnover in 2013 was due to innovative qoods or services that have been introduced since Januarv 2011?

Source: Calculated by authors from data in Flash Eurobarometer 394 using STATA.

The first step towards the introduction of an innovation is the initial idea. This idea can come either from employees or management or from the external environment such as other companies, universities, public sector or consumers. The average contributions of these subjects to the development of the ideas for innovation are shown in Figure 5. 
Huňady, J. - Orviská, M. - Šarkanová, B.: Determinants of European Firm 's Innovation and the Role of Public Financial Support.

Fig. 5: The contribution of subjects to development of ideas

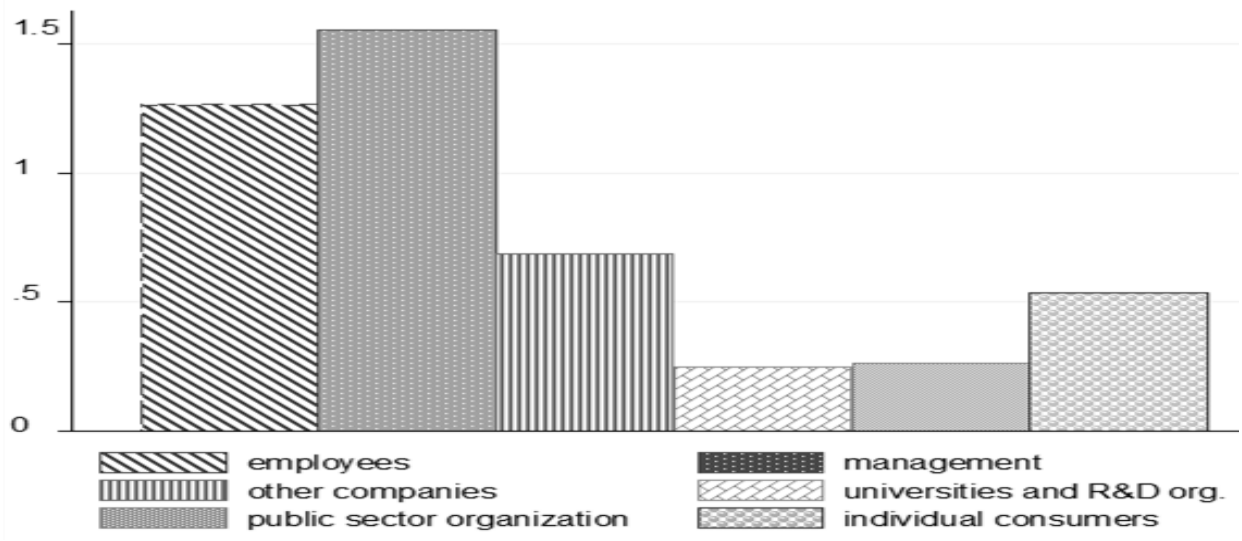

Source: Calculated by authors from data in Flash Eurobarometer 394 using STATA.

Respondents can choose whether each of these subjects contribute a lot, contribute a little or has not contributed at all on the development of ideas for innovations. We recode the answers on an ordered scale from 0 (not contribute at all) to 2 (contribute a lot). As we can see most of the firms claim that management and employees contributed the most, following by other companies and individual consumers. The contribution of public sector and universities is rather low, but not completely negligible. More than $22 \%$ of firms have reported that public sector organizations contributed in some extent to the development of these ideas. Referring to universities more than $20 \%$ of firms has found them more or less beneficial in this sense. We also found that larger companies more often considered the universities as well as public sector organization beneficial for the ideas than smaller firms. These differences are mostly significant in the case of universities. We can assume that the, larger companies have better connections to universities as well as a better ability to further develop and apply their ideas.

The impact of public sector organizations and universities on the development of ideas is different among the EU countries. The contribution of public sector organizations is highest in Finland, Latvia and Portugal. On the other hand, the smallest contribution of the public sector has been reported in Slovakia, Hungary and Slovenia. The contribution of universities is most evident in Finland, Sweden and Belgium and this contribution is least often reported in Luxembourg, Slovakia and Estonia. 
As we have stated before external financial support could be an important factor in the innovation process. The funding may be carried out by local or regional government, national government, the European Union or some other institution. Figure 6 illustrate the number of firms receiving public financial support for research and development or other innovation activities in different countries since January 2011. Firms from Finland, Netherlands and Luxembourg most often received the financial support from national government. The national government support seems to be also rather high in Croatia, Ireland and Malta, which are other good performers in innovation. The local or regional government support is very common in the case of firms from Belgium and Austria. On the other hand, the financial support from European Union is most frequently used in Latvia, Poland and Hungary. Firms from Slovakia received significantly less financial support for firm's innovation activities than average from all three sources and this support looks much higher in neighbouring countries such as Czech Republic, Hungary or Poland.

\section{Fig. 6: The share of firms receiving financial support on $R \& D$ or other innovation activities from selected subjects}

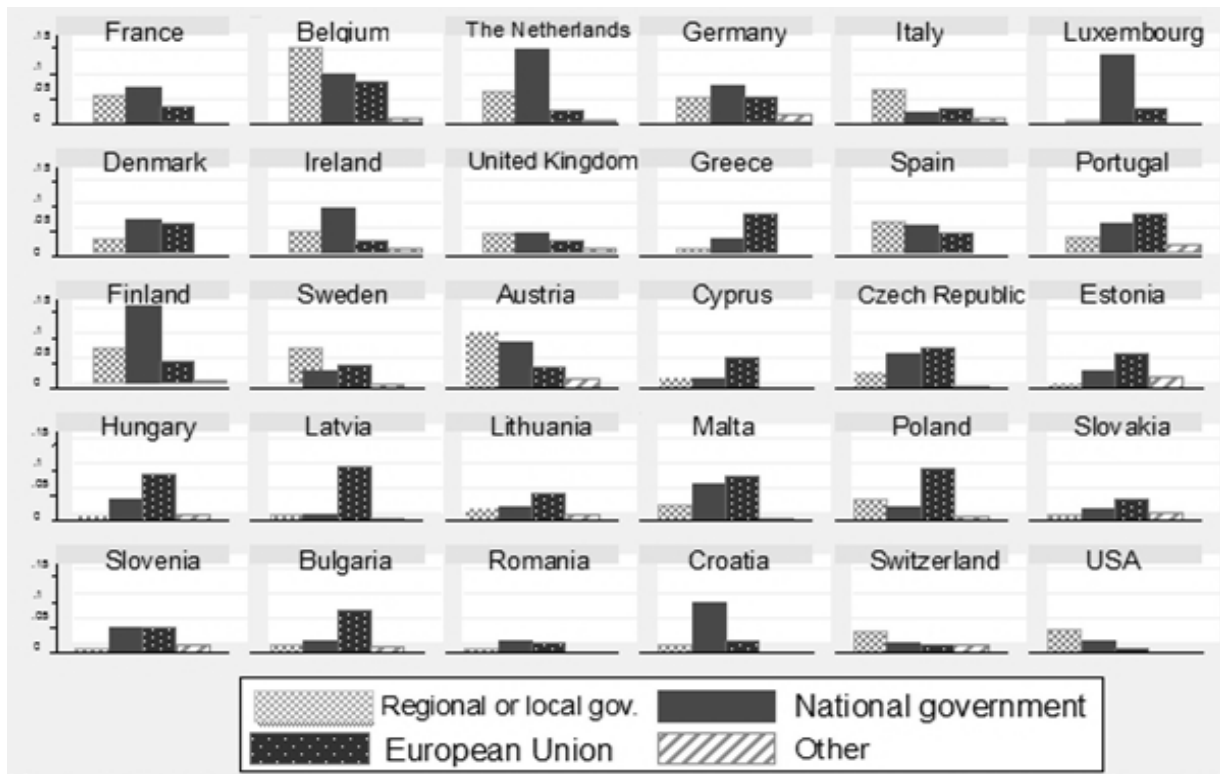

Has your company received any public financial support for research and development or other innovation activities from any of the following since January 2011?

Source: Calculated by authors from data in Flash Eurobarometer 394 using STATA. 
Figure 7 provides a closer look at the importance of this financial support for the development of innovation. Almost $20 \%$ of firms considered this financial support as indispensable for the development of innovation, which is also the most common answer. Despite this fact, the answers are relatively evenly dispersed on the scale and more than $16 \%$ of firms stated that the innovation would have been developed even without the support.

Fig. 7: The importance of financial support ( 1 to 6$)$

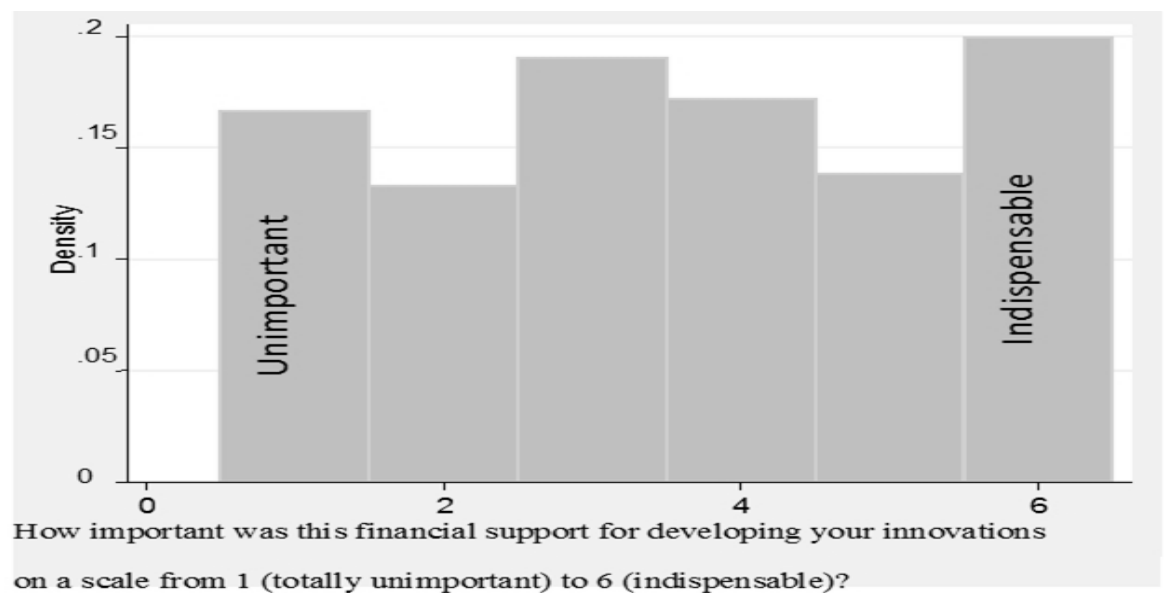

Source: Calculated by authors from data in Flash Eurobarometer 394 using STATA.

The financial support has been most important for the firms in Romania, Hungary, Ireland, Bulgaria and Lithuania and least important for firms from Netherlands, Luxembourg, Great Britain, Denmark and Austria (see Figure 8). Thus, the importance of the financial support seems to be higher mostly in the countries where the financial support is less common. Perhaps, this could be due to worse financial condition of firms, less available financial resources or better-targeted support in these countries. Alternatively it may reflect the declining marginal productivity of such support. 
Fig. 8: The importance of financial support (1 to 6$)$

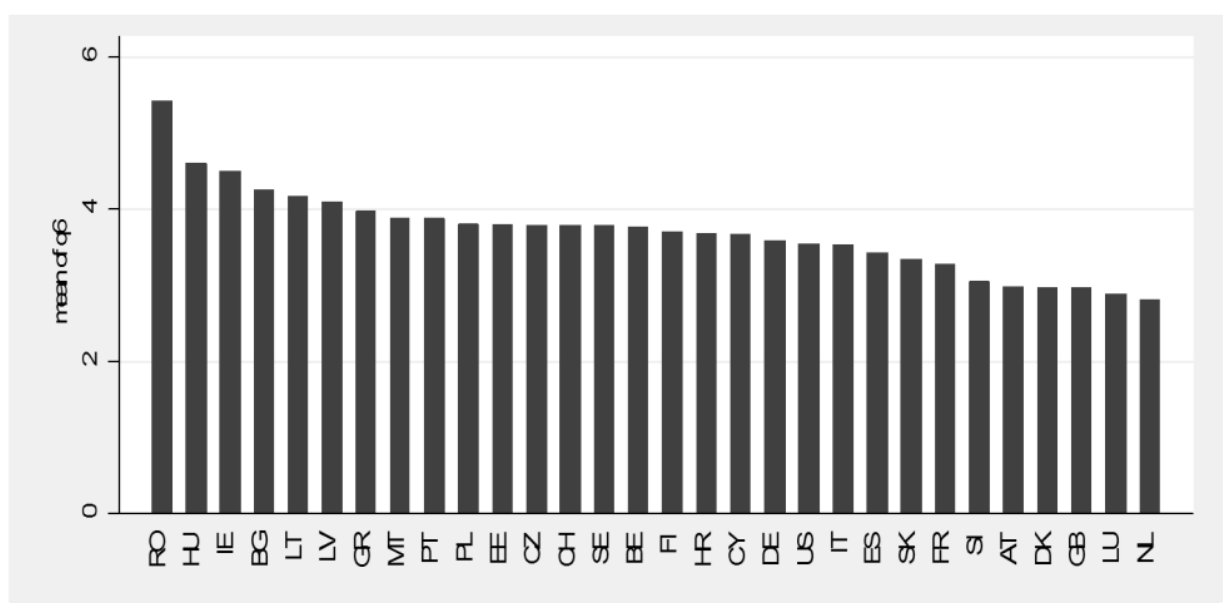

Source: Calculated by authors from data in Flash Eurobarometer 394 using STATA.

Despite relatively small differences based on the number of employees, the small and medium firms slightly tend to perceive the financial support as more important for innovations than large firms. The same is true for the total turnover of these firms. Firms with lower turnover on average considered the financial support as more important for the introduction of their innovation.

We further perform regression analysis in order to identify the potential significant determinants of innovation in the firms. The results of probit and logit regressions are summarized in Table 2. The results of logit regressions reported odds ratios are summarized in Annex 1. The innovation of goods, services and processes has been used as a binary depended variable. As it can be seen the number of employees is a significant factor for the innovation of services and processes, but not for goods innovation. Companies with more employees tend to introduce more service and process innovations. Thus, the innovation of goods seems to be less related to the age and size of the company compared to the innovation of processes or services. This is also supported with the next result that firms that have been founded earlier have higher probability of introduced innovation of services only and firms with higher total turnover are more likely to innovate their processes. Export focused companies tends to innovate goods and processes but not services, which is fully in line with the existence of several constraints of exporting services. The differences are also significant among the different sectors of economy. In the case of goods innovation, 
manufacturing firms are more than 2.7 times more likely to introduce this kind of innovation. The similar is true for the retail sector. In the case of services innovation it is obvious that the sector of services is the most active in this field. On the other hand, firms, which are active in manufacturing sector, have lower probability of doing this kind of innovation but they seem to be the leaders in the innovation of processes.

When focusing attention on different countries, the firms from the original EU member states (EU 15) are more likely to introduce new or significantly improved goods. However, this is not a significant factor for the innovation of services or processes. A relatively surprising fact is that firms from Slovakia appear to be significantly more active in the innovation of goods and services than the average, given their characteristics. The results also suggest that firms from Poland are the most active in developing goods and services innovation from Visegrad four countries. The odds of introducing this kind of innovation are approximately 1.5 higher in comparison to odds of any other average "non-Polish" firm. On the other hand, the probability of introducing innovative services or processes is less than half for Hungarian firms. Similarly, the innovation of goods is significantly less frequent in the case of firms from Hungary.

The next set of independent variables in Table 2 is related to collaboration with external subjects, market competition and financial support. The results suggest that firms collaborating with clients and partner companies for the marketing, distribution or promotion of any of their goods (no matter whether they are innovative or not) are more likely to introduce new goods services or processes. Thus the cooperation with these partners appears to be effective in supporting innovations. However, in this case there can be a potential problem with some kind of reverse causality, or endogenity. Firms that are doing more innovative products could be probably more open to cooperation with partner firms or clients in marketing, distribution or promotion of these products. 
Tab. 2: The results of probit and logit regression models

\begin{tabular}{|c|c|c|c|c|c|c|}
\hline & \multicolumn{2}{|c|}{ Goods } & \multicolumn{2}{|c|}{ Services } & \multicolumn{2}{|c|}{ Processes } \\
\hline & $\begin{array}{c}\text { Logit: } \\
\text { Odds } \\
\text { Ratios }\end{array}$ & $\begin{array}{l}\text { Probit: } \\
\text { Marginal } \\
\text { Effects } \\
(\mathbf{d y} / \mathbf{d x}) \\
\end{array}$ & $\begin{array}{r}\text { Logit: } \\
\text { Odds } \\
\text { Ratios }\end{array}$ & $\begin{array}{l}\text { Probit: } \\
\text { Marginal } \\
\text { Effects } \\
\text { (dy/dx) }\end{array}$ & $\begin{array}{r}\text { Logit: } \\
\text { Odds } \\
\text { Ratios }\end{array}$ & $\begin{array}{l}\text { Probit: } \\
\text { Marginal } \\
\text { Effects } \\
(\text { dy/dx }) \\
\end{array}$ \\
\hline $\begin{array}{l}\text { Number of } \\
\text { employees }\end{array}$ & $\begin{array}{c}0.99 \\
(-0.09)\end{array}$ & $\begin{array}{l}-0.0001 \\
(-0.00)\end{array}$ & $\begin{array}{l}1.08 * * \\
(2.41)\end{array}$ & $\begin{array}{c}0.016^{* *} \\
(2.32)\end{array}$ & $\begin{array}{c}1.25^{* * * *} \\
(6.62)\end{array}$ & $\begin{array}{c}0.043 * * * \\
(6.66)\end{array}$ \\
\hline $\begin{array}{l}\text { Foundation date } \\
\text { of the firm }\end{array}$ & $\begin{array}{c}0.98 \\
(-0.31)\end{array}$ & $\begin{array}{l}-0.005 \\
(-0.38)\end{array}$ & $\begin{array}{c}1.31 * * * \\
(4.28)\end{array}$ & $\begin{array}{c}0.058^{* * * *} \\
(4.3)\end{array}$ & $\begin{array}{c}1.02 \\
(0.21)\end{array}$ & $\begin{array}{l}0.026 \\
(0.20)\end{array}$ \\
\hline Total turnover & $\begin{array}{c}1.02 \\
(0.91)\end{array}$ & $\begin{array}{l}0.004 \\
(0.85)\end{array}$ & $\begin{array}{c}1.01 \\
(0.19)\end{array}$ & $\begin{array}{l}0.0012 \\
(0.26)\end{array}$ & $\begin{array}{c}1.10^{* * * *} \\
(3.78)\end{array}$ & $\begin{array}{c}0.018 * * * \\
(3.84)\end{array}$ \\
\hline Export focus & $\begin{array}{c}1.11 * * * \\
(6.35)\end{array}$ & $\begin{array}{c}0.022 * * * \\
(6.41)\end{array}$ & $\begin{array}{c}0.96^{* * * *} \\
(-2.65)\end{array}$ & $\begin{array}{c}-0.01 * * * \\
(-2.77)\end{array}$ & $\begin{array}{c}1.05^{* * *} \\
(2.82)\end{array}$ & $\begin{array}{c}0.01 * * * \\
(2.88)\end{array}$ \\
\hline $\begin{array}{l}\text { Selling to individ. } \\
\text { consumers }\end{array}$ & $\begin{array}{c}1.34 * * * * \\
(5.76)\end{array}$ & $\begin{array}{c}0.060 * * * \\
(5.90)\end{array}$ & $\begin{array}{c}1.20^{* * * *} \\
(3.72)\end{array}$ & $\begin{array}{c}0.039 * * * \\
(3.71)\end{array}$ & $\begin{array}{c}1.22 * * * * \\
(3.79)\end{array}$ & $\begin{array}{c}0.038 * * * \\
(3.76)\end{array}$ \\
\hline $\begin{array}{l}\text { Selling to public } \\
\text { sector }\end{array}$ & $\begin{array}{c}0.17 * * * * \\
(3.14)\end{array}$ & $\begin{array}{c}0.031 * * * \\
(3.16)\end{array}$ & $\begin{array}{c}1.41 * * * \\
(7.33)\end{array}$ & $\begin{array}{c}0.074 * * * \\
(7.38)\end{array}$ & $\begin{array}{c}1.07 \\
(1.40)\end{array}$ & $\begin{array}{l}0.014 \\
(1.47)\end{array}$ \\
\hline Manufacturing & $\begin{array}{l}2.76^{* * *} \\
(15.37)\end{array}$ & $\begin{array}{c}0.202 * * * \\
(15.94)\end{array}$ & $\begin{array}{c}0.73 * * * \\
(-4.22)\end{array}$ & $\begin{array}{c}-0.065^{* * *} \\
(-4.07)\end{array}$ & $\begin{array}{c}1.31 * * * \\
(3.85)\end{array}$ & $\begin{array}{c}0.053 * * * \\
(3.86)\end{array}$ \\
\hline Industry & $\begin{array}{c}1.21 * * * \\
(2.76)\end{array}$ & $\begin{array}{c}0.036 * * * \\
(2.69)\end{array}$ & $\mathrm{X}$ & $\mathrm{X}$ & $\begin{array}{c}0.89 \\
(1.56)\end{array}$ & $\begin{array}{l}-0.022 \\
(-1.62)\end{array}$ \\
\hline Retail & $\begin{array}{c}2.51 * * * \\
(14.82)\end{array}$ & $\begin{array}{c}0.182 * * * \\
(15.35)\end{array}$ & $\begin{array}{l}1.16^{*} \\
(2.27)\end{array}$ & $\begin{array}{c}0.033 * * \\
(2.32)\end{array}$ & $\mathrm{X}$ & $\mathrm{X}$ \\
\hline Services & $\mathrm{X}$ & $\mathrm{X}$ & $\begin{array}{c}1.50^{* * * *} \\
(6.39)\end{array}$ & $\begin{array}{c}0.087 * * * \\
(6.48)\end{array}$ & $\begin{array}{c}0.94 \\
(-0.94)\end{array}$ & $\begin{array}{l}-0.012 \\
(-0.97)\end{array}$ \\
\hline Slovakia & $\begin{array}{l}1.40 * * \\
(2.59)\end{array}$ & $\begin{array}{c}0.067 * * * \\
(2.60)\end{array}$ & $\begin{array}{l}1.29 * * \\
(2.06)\end{array}$ & $\begin{array}{c}0.054 * * \\
(2.04)\end{array}$ & $\begin{array}{c}0.90 \\
(-0.82)\end{array}$ & $\begin{array}{l}-0.020 \\
(-0.78)\end{array}$ \\
\hline Czech republic & $\begin{array}{c}0.87 \\
(-1.03)\end{array}$ & $\begin{array}{l}-0.026 \\
(-1.01)\end{array}$ & $\begin{array}{c}1.06 \\
(0.48)\end{array}$ & $\begin{array}{l}0.013 \\
(0.52)\end{array}$ & $\begin{array}{c}0.77^{*} \\
(-1.96)\end{array}$ & $\begin{array}{l}-0.048^{*} \\
(-1.93)\end{array}$ \\
\hline Poland & $\begin{array}{c}1.53 * * * \\
(3.8)\end{array}$ & $\begin{array}{c}0.086 * * * \\
(3.82)\end{array}$ & $\begin{array}{c}1.50^{* * * *} \\
(3.74)\end{array}$ & $\begin{array}{c}0.086^{* * * *} \\
(3.73)\end{array}$ & $\begin{array}{c}0.95 \\
(-0.40)\end{array}$ & $\begin{array}{l}-0.009 \\
(-0.40)\end{array}$ \\
\hline Hungary & $\begin{array}{l}0.75 * * \\
(-2.13)\end{array}$ & $\begin{array}{c}-0.056 * * \\
(-2.17)\end{array}$ & $\begin{array}{c}-0.48 * * * \\
(-5.24)\end{array}$ & $\begin{array}{c}-0.152 * * * \\
(-5.39)\end{array}$ & $\begin{array}{c}0.49 * * * \\
(-4.90)\end{array}$ & $\begin{array}{c}-0.135 * * * \\
(-5.02)\end{array}$ \\
\hline EU 15 & $\begin{array}{c}1.17 * * * \\
(2.77)\end{array}$ & $\begin{array}{c}0.031 * * * \\
(2.77)\end{array}$ & $\begin{array}{l}0.91 * \\
(-1.69)\end{array}$ & $\begin{array}{c}-0.021 * \\
(-1.77)\end{array}$ & $\begin{array}{c}0.92 \\
(-1.62)\end{array}$ & $\begin{array}{l}-0.017 \\
(-1.57)\end{array}$ \\
\hline
\end{tabular}


Huňady, J. - Orviská, M. - Šarkanová, B.: Determinants of European Firm 's Innovation and the Role of Public Financial Support.

\begin{tabular}{|c|c|c|c|c|c|c|}
\hline & \multicolumn{2}{|c|}{ Goods } & \multicolumn{2}{|c|}{ Services } & \multicolumn{2}{|c|}{ Processes } \\
\hline & $\begin{array}{l}\text { Logit: } \\
\text { Odds } \\
\text { Ratios }\end{array}$ & $\begin{array}{l}\text { Probit: } \\
\text { Marginal } \\
\text { Effects } \\
(\text { dy/dx) } \\
\end{array}$ & $\begin{array}{l}\text { Logit: } \\
\text { Odds } \\
\text { Ratios }\end{array}$ & $\begin{array}{l}\text { Probit: } \\
\text { Marginal } \\
\text { Effects } \\
\text { (dy/dx) } \\
\end{array}$ & $\begin{array}{c}\text { Logit: } \\
\text { Odds } \\
\text { Ratios }\end{array}$ & $\begin{array}{l}\text { Probit: } \\
\text { Marginal } \\
\text { Effects } \\
\text { (dy/dx) } \\
\end{array}$ \\
\hline $\begin{array}{l}\text { Collaboration } \\
\text { with competitors }\end{array}$ & $\begin{array}{l}0.87 * \\
(-1.9)\end{array}$ & $\begin{array}{l}-0.027^{*} \\
(-1.89)\end{array}$ & $\begin{array}{l}1.18 \\
(1.6)\end{array}$ & $\begin{array}{l}0.024 \\
(1.65)\end{array}$ & $\begin{array}{l}1.14^{*} \\
(1.85)\end{array}$ & $\begin{array}{l}0.026^{*} \\
(1.84)\end{array}$ \\
\hline $\begin{array}{l}\text { Collaboration } \\
\text { with partners }\end{array}$ & $\begin{array}{l}1.53 * * * \\
(8.06)\end{array}$ & $\begin{array}{c}0.085^{* * * *} \\
(8.08)\end{array}$ & $\begin{array}{c}1.48 * * * \\
(7.62)\end{array}$ & $\begin{array}{c}0.083 * * * \\
(7.64)\end{array}$ & $\begin{array}{c}1.55^{* * * *} \\
(8.33)\end{array}$ & $\begin{array}{c}0.085 * * * \\
(8.41)\end{array}$ \\
\hline $\begin{array}{l}\text { Collaboration } \\
\text { with clients }\end{array}$ & $\begin{array}{l}1.54 * * * \\
(8.19)\end{array}$ & $\begin{array}{c}0.087 * * * * \\
(8.25)\end{array}$ & $\begin{array}{c}1.37 * * * \\
(6.1)\end{array}$ & $\begin{array}{c}0.068 * * * \\
(6.13)\end{array}$ & $\begin{array}{l}1.32 * * * \\
(5.15)\end{array}$ & $\begin{array}{c}0.053 * * * \\
(5.20)\end{array}$ \\
\hline $\begin{array}{l}\text { Collaboration } \\
\text { with public } \\
\text { sector }\end{array}$ & $\begin{array}{c}0.87 * \\
(-1.75)\end{array}$ & $\begin{array}{l}-0.028^{*} \\
(-1.72)\end{array}$ & $\begin{array}{c}1.08 \\
(0.93)\end{array}$ & $\begin{array}{l}0.015 \\
(0.89)\end{array}$ & $\begin{array}{c}0.93 \\
(-0.93)\end{array}$ & $\begin{array}{l}-0.014 \\
(-0.89)\end{array}$ \\
\hline $\begin{array}{l}\text { Strength of the } \\
\text { competition }\end{array}$ & $\begin{array}{l}1.13 * * * \\
(3.99)\end{array}$ & $\begin{array}{c}0.024 * * * \\
(3.91)\end{array}$ & $\begin{array}{l}1.024 \\
(0.8)\end{array}$ & $\begin{array}{l}0.005 \\
(0.82)\end{array}$ & $\begin{array}{l}1.03 \\
(0.98)\end{array}$ & $\begin{array}{l}0.006 \\
(1.00)\end{array}$ \\
\hline $\begin{array}{l}\text { Local gov. } \\
\text { financial support }\end{array}$ & $\begin{array}{c}1.12 \\
(0.93)\end{array}$ & $\begin{array}{l}0.023 \\
(0.98)\end{array}$ & $\begin{array}{l}1.24 * \\
(1.89)\end{array}$ & $\begin{array}{c}0.046^{*} \\
(1.91)\end{array}$ & $\begin{array}{l}1.28 * * \\
(2.12)\end{array}$ & $\begin{array}{l}0.049 * * \\
(2.18)\end{array}$ \\
\hline $\begin{array}{l}\text { National gov. } \\
\text { financial support }\end{array}$ & $\begin{array}{l}1.48 * * * \\
(3.77)\end{array}$ & $\begin{array}{c}0.078 * * * \\
(3.78)\end{array}$ & $\begin{array}{l}1.28 * * \\
(2.48)\end{array}$ & $\begin{array}{l}0.052 * * \\
(2.48)\end{array}$ & $\begin{array}{l}1.31 * * * \\
(2.62)\end{array}$ & $\begin{array}{c}0.051 * * \\
(2.59)\end{array}$ \\
\hline $\begin{array}{l}\text { EU financial } \\
\text { support }\end{array}$ & $\begin{array}{l}1.34 * * * \\
(2.79)\end{array}$ & $\begin{array}{c}0.058 * * * \\
(2.82)\end{array}$ & $\begin{array}{l}1.24 * * \\
(2.15)\end{array}$ & $\begin{array}{l}0.045^{* *} \\
(2.12)\end{array}$ & $\begin{array}{l}1.40 * * * \\
(3.28)\end{array}$ & $\begin{array}{c}0.065 * * * \\
(3.28)\end{array}$ \\
\hline $\begin{array}{l}\text { Other financial } \\
\text { support }\end{array}$ & $\begin{array}{c}0.94 \\
(-0.24)\end{array}$ & $\begin{array}{l}-0.011 \\
(-0.22)\end{array}$ & $\begin{array}{c}1.10 \\
(0.39)\end{array}$ & $\begin{array}{l}0.020 \\
(0.4)\end{array}$ & $\begin{array}{c}1.28 \\
(0.99)\end{array}$ & $\begin{array}{l}0.051 \\
(1.05)\end{array}$ \\
\hline Carried out R\&D & $\begin{array}{l}2.89 * * * \\
(19.52)\end{array}$ & $\begin{array}{c}0.215 * * * \\
(20.82)\end{array}$ & $\begin{array}{c}2.43 * * * \\
(16.5)\end{array}$ & $\begin{array}{c}0.191 * * * \\
(16.58)\end{array}$ & $\begin{array}{l}2.75 * * * \\
(18.9)\end{array}$ & $\begin{array}{c}0.199 * * * \\
(19.97)\end{array}$ \\
\hline Observations & 9845 & 9845 & 9845 & 9845 & 9845 & 9845 \\
\hline Log likelihood & -5734.49 & -5733.82 & -6029.29 & -6028.88 & -5603.13 & -5600.52 \\
\hline $\mathbf{L R} \mathbf{X}^{2}$ & 1663.54 & 1664.89 & 1047.64 & 1048.45 & 1488.21 & 1493.4 \\
\hline $\begin{array}{l}\text { Correctly } \\
\text { classified }\end{array}$ & $69.79 \%$ & $69.85 \%$ & $66.83 \%$ & $66.80 \%$ & $71.02 \%$ & $70.97 \%$ \\
\hline
\end{tabular}

Source: Authors calculations using STATA.

Notes: The odds ratios are calculated for the logit models and the marginal effects are calculated for the probit models; (.) denotes $\mathrm{z}$ - statistics and $* / * * / * * *$ means significance at the $10 \% / 5 \% / 1 \%$ levels. 
Collaboration with competitors and public sector seems to have a slightly adverse effect on innovation of goods. Collaboration with competitors could be seen as the sign of weak market competition or the manifestation of cartels and this could reduce the motivation of firms to innovate. This is supported with high significance of the variable reflecting the market competition strength reported by the firms in the sample. We can say that stronger competition could lead into a higher probability of introducing innovative goods, but according to our results this is not evident for services and processes.

The financial support seems to be also very important for innovation. Based on the regressions results, the firms, which get the financial support from national government or EU for research and development or other innovation activities, have indeed introduced more innovation. This is equally true for innovation of goods, services and processes and it confirms the efficiency of this support. The evidence for the effect of regional support appears to be not significant in the case of goods, weak significant for services and significant for processes. The financial support from other institution seems to be ineffective in this sense. The results could reflect the fact that financial support from national governments and EU could be conditional, which means that firms have an obligation to develop the innovation. We can also assume that the financial support from government or EU could be better targeted as well as more conditional than the financial support from other institution.

The R\&D and its support are probably the main source of innovation in the firms. Our results suggest that firms which have carried out research and development either in house or by subcontracting are almost 3 times more active in introducing innovative goods. Moreover, we get similar results also for the innovation of services where the odds ratio is 2.43 and for the processes where the odds ratio is more than 2. These results are of course fully in line with our previous assumption.

\section{Conclusion}

Innovations represent the key driver of productivity and performance in companies improving their competitiveness, and consequently an important factor supporting economic growth. Outcomes of innovation activities may frequently take the form of new or improved goods, services, processes, marketing strategies or organizational structures. There are many determinants influencing the innovation process on firmlevel. In this paper we tried to identify the most important ones. 
The dataset we used comes from Flash Eurobarometer 394 survey carried out in early 2014. Although the survey has been conducted not only in $28 \mathrm{EU}$ member states, but also in Switzerland and USA, we analysed data especially from the EU. The survey covers issues related to innovation activities, commercialization of innovation and also public support, therefore we performed an analysis of the answers on selected questions by country and subsequently we performed regression analysis.

Some of the interesting results can be summarized as follows. According to the survey, a positive relationship has been identified between the innovation of services and innovation of goods in countries considered as innovation leaders and contrariwise. Although innovations of processes are less common, their appearance is also more frequent in the countries that lead the innovation ranking. The primary motivation of companies to innovate is to raise their turnover resulting in higher profits, or to protect market share and protect profits. The innovation process in a firm can be initiated by internal subjects but also by external subjects such as other companies, universities, consumers or public sector. The results show that the initial impulse to innovate comes most often from company management, but employees also play a significant role as the source of innovative ideas. The impact of public sector or universities differs among the EU member states. Regarding the financing of innovations, firms most often receive support from the public sector national government, regional government or the European Union. This support has been proven to be substantial for the development of innovation, however it seems to be more important in countries where it is less common. The importance of financial support seems to be typical rather for small and medium firms and firms with relatively low turnover.

Based on the regression analysis there is evidence of different impacts of determinants on different types of innovation. We argue that the number of employees seems to be a significant factor for the innovation of services and processes. Older firms have a higher probability of introducing service innovations. In contrast, firms with higher turnover are more likely to innovate processes. The relationship between exports and innovations is shown to be significant in innovations in goods and processes, which reflects the obvious barriers to the export of services. Similar differences can be found also between the sectors of economy. According to the regression results, manufacturing firms are almost three times more successful innovators of goods. The most active sector of services is represented by the retail sector. Results of the analysis show that cooperation with other partners such as clients, partner companies 
appears to be having influence on the introduction of new goods, services or processes. Thus it appears to be an effective support for innovation. However, collaboration with competitors and public sector seems to be associated with a slight adverse effect on innovation of goods. The efficiency of financial support has been proven based on the regression results showing that financial support from the EU and national governments has significant influenced all types of innovations. In part this may reflect the conditionality of the mentioned financial support. On the other hand, regional support appears to be important especially for process innovations. Based on the results we are able to emphasize that the key determinant of company innovations is $R \& D$, either in house or subcontracted, and the financial support of these activities.

\section{References}

Acs, Z. J. - Audretsch, D. B. (1988): Innovation in Large and Small Firms: An Empirical Analysis. The American Economic Review, vol. 78, no. 4, pp. 678-690.

Aghion P. et al. (2005): Competition and innnovation: An Inverted- $U$ Relationship. Quarterly Journal of Economics, 2005, vol. 120, no. 2, pp. 701-728.

Benčo, J. - Kuviková, H. - Mikušová-Meričková, B. - Šebo, J. Štrangfeldová, J. (2011): Ekonomika verejných služieb. (The economy of public services). Banská Bystrica, Matej Bel University, Faculty of Economics, 2011.

Bekkers, V. - Homburg, V. (2007): The Myths of E-Government. The Information Society, 2007, vol. 23, no. 5, pp. 373-382.

Blind, K. (2012): The influence of regulations on innovation: A quantitative assessment for OECD countries. Research Policy, 2012, vol. 41, no. 2, pp. 391-400.

Boone J. - Van Dijk T. (1998): Competition and Innovation. De Economist, 1998, vol. 146, no. 3, pp. 445-461.

Boone J. (2001): Intensity of competition and the incentive to innovate. International Journal of Industrial Organization, 2001, vol. 19, no. 5, pp. 705-726.

Cohen, W. M. - Klepper, S., (1996): Firm Size and the Nature of Innovation within Industries: The Case of Process and Product $R \& D$. The Review of Economics and Statistics, 1996, vol. 78, no. 2, pp. 232243. 
Huňady, J. - Orviská, M. - Šarkanová, B.: Determinants of European Firm 's Innovation and the Role of Public Financial Support.

European Union (2014): Flash Eurobarometer 394 "The role of public support in the commercialisation of innovations". [on-line], 2014 [cited $5^{\text {th }}$ October 2014], <http://ec.europa.eu/public_opinion/flash/ fl_394_en.pdf>

Fagerberg, J. (2006): Innovation: A Guide to the Literature. In Fagerberg J., D.C. Mowery \& R. Nelson (2006), Oxford Handbook of Innovation, Oxford: OUP; pp. 1-27.

Greenhalgh, CH. - Rogers, M. (2010): Innovation, Intellectual Property and Economic Growth. Princeton, Princeton University Press, 2010.

Hall, B. H. (2005): The Financing of Innovation. [on-line], December 2005 [cited $9^{\text {th }}$ October 2014], <http://eml.berkeley.edu/ bhhall/papers/ BHH05_financing_innov_ShaneHB_chapter.pdf >

Jáč, I. - Rydvalová, P. - Žižka, M. (2005): Inovace v malém a středním podnikání. (Innovation in small and medium business). Brno, Computer Press, 2005.

Jang, W. S. - Chang, W. (2008): The Impact of Financial Support System on Technology Innovation: A Case of Technology Guarantee System in Korea. Journal of Technology Management \& Innovation, 2007, vol. 3, no. 1, pp. 10-16.

Kaldor, N. (1972): The Irrelevance of Equilibrium Economics. The Economic Journal, vol. 82, no. 328, pp. 1237-1255.

Klement, L. (2014): Selected Problems of Innovation Performance of Enterpises in the Slovak Republic. Kitekintés - Perspective, Magyarszlovák periodika, 2014, vol. 18, no. 20, pp. 56-66.

Koudelková, P. (2014): Innovation in Small and Medium Enterprises in the Czech Republic. Central European Business Review, 2014, vol. 3, no. 3, pp. 31-37.

Lesáková, L. (2014): Evaluating Innovations in Small and Medium Enterprises in Slovakia. Procedia - Social and Behavioral Sciences, The 2-nd International Scientific conference „Contemporary Issues in Business Management and Education 2013“, 2014, vol. 110, pp. 74-81.

Lisý, J. et al. (2007): Ekonómia v novej ekonomike. [Economy in new economics]. Bratislava, IURA edition, 2007.

Lerner (1999): The Government as Venture Capitalist: The Long-Run Impact of the SBIR Program, Journal of Business, 1999, vol. 72, no 3. pp. 285-318.

Lucas, R. (1988): On the mechanics of economic development. Journal of Monetary Economics, 1988, vol. 22, no. 1, pp. 3-42. 
Mulgan, G. - Albury, D. (2003): Innovation in the public sector. [online], ver1.9, October 2003 [cited $9^{\text {th }}$ October 2014], <http://www.childrencount.org/documents/Mulgan\%20on\%20Innovation. pdf $>$

Osborn, S. - Brown, K. (2005): Managing change and innovation in public service organizations. London: Routledge, 2005.

Sivák, R. - Čaplánová, A. - Hudson, J. (2011): The impact of governance and infrastructure on innovation. Post-Communist Economies, 2011, vol. 23, no. 2, pp. 203-217.

Scherer, F. M. (1992): Schumpeter and plausible capitalism. Journal of Economic Literature, vol. 30, no. 3, pp. 1416-1433.

Schumpeter, J. A. (1937): Theorie der Wirschaftlichen Entwicklung. Reprinted in Essays of J. A. Schumpeter, Cambridge, MA: AddisonWesley (2009).

Schumpeter, J. A. (1942): Capitalism, Socialism and Democracy. New York, Harper, 1942. 2011.

Solow, R. M. (1957): Technical Change and the Aggregate Production Function. Review of Economics and Statistics, 1957, vol. 39, number. 3. pp. 312-320.

Svidroňová, M. - Mikuš, T. (2014): Co-creation as the public service innovation. Acta Aerarii Publici, 2011, vol. 11, no. 1. pp. 76-91.

Šipikal, M., - Pisár, P. - Uramová, M. (2010): Support of innovation at regional level. E+M Economics and Management, 2010, vol. 13, no. 4, pp. 74-84.

Uramová, M. - Valach, E. - Paulík, T. (2003): Hospodárska politika. [The economic policy]. Banská Bystrica, Matej Bel University, Faculty of Economics, 2013.

Vieites, A. G. - Calvo, J. L. (2011): A Study on the Factors that Influence Innovation Activities of Spanish Big Firms. Technology and Investment, 2011, vol. 2, no. 1, pp. 8-19.

Zemplinerová, A. - Hromádková, E. (2012): Determinants of firm's innovation. Prague Economic Papers, 2012, vol. 2012, no. 4, pp. 487-503. Zemplinerová, A. (2010): Innovation Activity of Firms and Competition. Politická ekonomie, 2010, vol. 58, no. 6, pp. 747-760. 
Huňady, J. - Orviská, M. - Šarkanová, B.: Determinants of European Firm's Innovation and the Role of Public Financial Support.

\title{
Determinates of European Firm's Innovation and the Role of Public Financial Support
}

\begin{abstract}
Innovation activities at firm-level are often significantly influenced by factors that determine the outcome of the innovation process. The primary aim of this paper is to study and empirically verify the role of several determinants that affect company innovations in the European Union. The dataset for the analysis comes from Flash Eurobarometer 394 survey carried out in early 2014 and covers issues related to innovation activities, commercialization of innovation and also public support. We summarize the answers on selected questions from the survey by country, and subsequently based on the dataset, we perform regression analysis. In line with our primary assumptions, our results suggest that R\&D activities on firm-level and their support represent the key factors substantially responsible for innovations. The work emphasizes the importance of firm characteristics and substantial differences between different types of innovation. Public sector support of innovation is also crucial.
\end{abstract}

Key words: Innovation; Public support; Firm; R\&D activities.

JEL classification: O31, O30, L25 